\title{
Impact of the LH surge on granulosa cell transcript levels as markers of oocyte developmental competence in cattle
}

\author{
Isabelle Gilbert, Claude Robert, Christian Vigneault ${ }^{1}$, Patrick Blondin ${ }^{1}$ and Marc-André Sirard \\ Centre de Recherche en Biologie de la Reproduction, INAF, Université Laval, Québec, Québec, Canada G1V OA6 and \\ ${ }^{1} L^{\prime}$ Alliance Boviteq, 19320 Grand rang St-François, Saint-Hyacinthe, Québec, Canada J2T 5H1
}

Correspondence should be addressed to M-A Sirard; Email: marc-andre.sirard@fsaa.ulaval.ca

\begin{abstract}
In the case of in vitro embryonic production, it is known that not all oocytes detain the developmental capacity to form an embryo. This capacity appears to be acquired through completion of folliculogenesis, during which the oocyte and follicular cells influence their respective destinies. The differentiation status of granulosa cells (GCs) could therefore offer an indicator of oocyte quality. The aim of this study was to compare mRNA transcript abundance in GCs associated with oocytes that subsequently reach or not the blastocyst stage. GCs were collected from cattle following an ovarian stimulation protocol that did or did not include the administration of LH. GCs were classified according to the developmental stage achieved by the associated oocytes. Transcript abundance was measured by microarray. Follicles $(n=189)$ obtained from cows before and after the LH surge were essentially similar and the rates of oocytes reaching the blastocyst stage were not significantly different (52 vs $41 \%$ ), but blastocyst quality was significantly better in the post-LH-surge group. In GCs from the pre-LH-surge group and associated with developmentally competent oocytes, 18 overexpressed and 22 underexpressed transcripts were found, including novel uncharacterized transcripts, whereas no differentially expressed transcripts were associated with developmentally different oocytes in the post-LH-surge group. The novel transcriptomic response associated with $\mathrm{LH}$ appeared to mask the difference. Based on oocyte developmental competence, the period prior to the LH surge appears best suited for studying competence-associated mRNA transcripts in bovine follicle cells.
\end{abstract}

Reproduction (2012) 143 735-747

\section{Introduction}

In the cattle industry, in vitro embryo production (IVP) and embryo transfer have become useful for treating infertility in problematic animals or for accelerating genetic gain in fertile animals of high commercial value. These techniques provide effective means of decreasing generation time and thus increasing the speed of genetic progress in large mono-ovulating species. One of the major limitations of IVP comes from the variable quality of oocytes recovered, with or without hormonal treatments. Development to the blastocyst stage, achieved using unprimed animals or slaughterhouse ovaries, has not improved much over the past two decades. Indeed, only $30-40 \%$ of oocytes are able to develop to the blastocyst stage in vitro (Sirard et al. 1988, Wiemer et al. 1991, Ward et al. 2002), while more than $85 \%$ do so in vivo (Sirard et al. 1985).

The concept of oocyte developmental competence can be summarized as the ability of the oocyte to mature, develop to the blastocyst stage, implant, and generate viable offspring (Duranthon \& Renard 2001, Sirard et al. 2006). This competence is acquired through the sequential completion of meiotic, cytoplasmic, and molecular maturation steps during folliculogenesis (Sirard et al. 2006) and is difficult to ascertain a priori. Follicular classification based on morphological characteristics has been used in an attempt to predict the developmental potential of the enclosed oocyte, but has met with mitigated success (Blondin \& Sirard 1995). For example, follicular size is strongly correlated with oocyte quality, but is not the only criterion to consider. Indeed, some oocytes that originate from large follicles still fail to produce embryos, while oocytes from medium-sized follicles (5-9 mm) may yield viable embryos (Sirard et al. 2006). Commonly used to define oocyte competence in the context of IVP, simply reaching the blastocyst stage is a relatively good indicator of oocyte overall quality.

Evidence accumulated over the past few decades suggests that a bidirectional communication between the oocyte and the surrounding somatic cells takes place during folliculogenesis (Buccione et al. 1990a, 1990b, Eppig et al. 2002, Gilchrist et al. 2004, Makabe et al. 2006, Sirard et al. 2006, Buratini \& Price 2011, Conti et al. 2012), confirming a link between oocyte 
competence and the follicular environment. This communication can be achieved through paracrine signaling and direct cell-to-cell communication via gap junction channels (reviewed in Kidder \& Vanderhyden (2010)). Growth and development, acquisition of meiotic and developmental competence, and regulation of overall transcriptional activity in oocytes rely on granulosa cell (GC) support (Eppig 1991, De La Fuente \& Eppig 2001, Eppig et al. 2005). However, oocytes in turn guide GC development and metabolic processes ( $\mathrm{Li}$ et al. 2000, Matzuk et al. 2002, Gilchrist et al. 2008).

GC could be a very convenient source of molecular markers of oocyte developmental potential, since they are simply discarded during oocyte collection in IVP procedures and their recovery does not require destruction of the gamete itself. In cattle and other species, molecular markers of oocyte developmental competence have been identified in surrounding GC and constitute an interesting avenue to investigate (Robert et al. 2001, Hamel et al. 2008, 2010a, 2010b, Jiang et al. 2010).

The aim of this study was thus to use GC obtained at the time of cumulus-oocyte complex (COC) collection to determine gene patterns in follicles containing oocytes capable of sustaining early embryonic development. Moreover, since the LH surge could have the final say on oocyte quality, we investigated GC preovulation transcripts just before and after the LH surge in the hope of finding molecular markers indicative of oocyte quality and thus identifying means of increasing the efficiency of IVP. Our goal was to describe the impact of the LH surge on the GC transcriptome, in addition to finding biomarkers that are associated with the presence of a developmentally competent gamete.

\section{Results}

\section{Ovarian stimulation protocol and follicle retrieval}

A summary of the number of follicles (i.e. COC) collected, the number of fertilized ooctyes that underwent at least one cleavage, and number that reached the blastocyst stage for the protocols 'pre- $\mathrm{LH}^{\prime}$ and 'post- $\mathrm{LH}^{\prime}$ is presented in Table 1. It should be noted that the pre-LH group contained a smaller number of follicles due to a hemorrhagic ovarian cyst forcing the exclusion of one cow from the study. The distribution of the follicles among the various size ranges is shown in Fig. 1. The different sizes observed were not statistically supported, due to the small number of samples. For both stimulation protocols, mid-sized follicles $(6-10 \mathrm{~mm})$ were predominant $(60-70 \%)$.

\section{Impact of the LH surge on follicular dynamics and embryonic development}

To classify GC in terms of embryonic developmental competence status, the COC of each follicle was removed and fertilized in vitro. The developmental stage reached in relation to follicular size and the numbers of embryos found at each stage are represented in Fig. 2. No statistical difference was observed between the two stimulation protocols in terms of failure of the fertilized oocytes to cleave $(21 \%$ in the post-LH group compared to $11 \%$ in the pre-LH group). A slightly but not significantly higher number of fertilized oocytes from the pre-LH group reached the blastocyst stage (52 vs $41 \%$ ). For both cleavage and blastocyst scores, one cow responded differently to treatment, indicative of a normal heterogeneous population.

\section{Impact of the $\mathbf{L H}$ surge on blastocyst quality}

The developmental and morphological status of each blastocyst was scored on day 9 of incubation. Figure 3 shows the percentages of blastocysts in each status category. A significantly greater number of category $5 \mathrm{~A}$ blastocysts (i.e. fully hatched, the most advanced blastocyst phase) were found in the post-LH group.

\section{Impact of the $\mathbf{L H}$ surge on differential gene expression in GC associated with 'competent' and 'incompetent' oocytes}

As a quality assessment step, the reproducibility of the microarray hybridization was evaluated using a signal intensity correlation matrix between replicate experiments for each GC group (pre-LH and post-LH) in a pairwise manner. An excellent correlation (0.95-0.99, data not shown) was found between the biological and technical replicates, indicative of a high homogeneity between treatments.

In the pre-LH group, microarray analyses between 'competent' vs 'incompetent' categories revealed 130 overexpressed and 206 underexpressed transcripts (foldchange $\geq 1.5$ and FDR $\leq 0.05$ ), whereas no over- or

Table 1 Summary of bovine embryo development obtained in vitro.

\begin{tabular}{|c|c|c|c|c|}
\hline $\begin{array}{l}\text { Stimulation } \\
\text { protocol }\end{array}$ & $\begin{array}{l}\text { Number } \\
\text { of cows }\end{array}$ & $\begin{array}{c}\text { Number of } \\
\text { follicles }(\mathrm{COC})\end{array}$ & $\begin{array}{c}\text { Underwent at least } \\
\text { one cleavage }(\%)\end{array}$ & $\begin{array}{l}\text { Reached the } \\
\text { blastocyst stage }\end{array}$ \\
\hline Pre-LH & $5^{a}$ & 84 & $74(88.1)$ & $44\left(52.4 \%, 59.5 \%{ }^{b}\right)$ \\
\hline Post-LH & 6 & 105 & $84(80.0)$ & $43\left(41.0 \%, 51.1 \% \mathrm{o}^{\mathrm{b}}\right)$ \\
\hline
\end{tabular}

${ }^{\mathrm{a}}$ One had a hemorrhagic cyst on an ovary and therefore was excluded. ${ }^{\mathrm{b}}$ Based on the number that underwent at least one cleavage. 
underexpressed signal was found in the post-LH group (Fig. 4), suggesting that the LH surge probably masked all further differences at that stage. After eliminating redundant transcripts, a total of 18 unique transcripts were identified as being upregulated and 22 unique transcripts as being downregulated in the pre-LH GC group and correlated with the developmental competence of the oocyte. Each overexpressed and underexpressed signal found was sequenced and is identified in Table 2. Among the downregulated transcripts, a predominance of genes associated with mitochondrial and ribosomal proteins were found. Some sequences identified in the microarray analyses were not related to any known genes, despite their positioning on the bovine genome, suggesting the presence of novel transcribed regions (NTRs) linked to oocyte developmental competence status.

\section{Molecular marker validation}

Validation of the molecular markers found in microarray analyses was performed using qRT-PCR. Five different transcripts and an expressed sequenced tag corresponding to an NTR upregulated and one downregulated transcript were analyzed in the $2 \mathrm{~h}$ pre-LH and $6 \mathrm{~h}$ post-LH groups (Fig. 5). For the pre-LH protocol, all of the transcripts (apoptotic chromatin condensation inducer 1 (ACIN1), inhibin beta A (INHBA), serglycin $(S R G N)$, tribbles homolog 2 (TRIB2), sterol-C4-methyl oxidase (MSMO1 (SC4MOL)), and NTR3) were statistically more abundant in the 'competent' group $(P<0.05)$, whereas TNFAIP6 mRNA was found to be more expressed $(P<0.05)$ in the incompetent group in concordance with microarray results. These differences were not found in the post-LH case (Fig. 5B).

\section{Pre-LH-surge GC associated with oocyte competence contain an abundance of transcripts of genes known to play a role in lipid metabolism and apoptosis}

To evaluate whether the differentially expressed transcripts identified through microarray analysis interact with each other, markers associated with known genes were subjected to pathway analysis. Twelve upregulated markers in GC associated with a competent oocyte were linked together in a network implicated in lipid metabolism, molecular transport, and small molecule biochemistry, reflecting GC physiological functions (Fig. 6A). Fifteen downregulated transcripts were assembled in a network involved in cell death and cell morphology (Fig. 6B). Since follicular atresia results from apoptosis, downregulation of the transcripts in this network may indicate actively growing and proliferating GC.

\section{Discussion}

The LH surge plays a critical role in folliculogenesis by inducing extreme reorganization in follicular cells, which in turn results in ovulation and luteinization. In the present study, we sought to investigate whether LH administered in ovarian stimulation protocols can

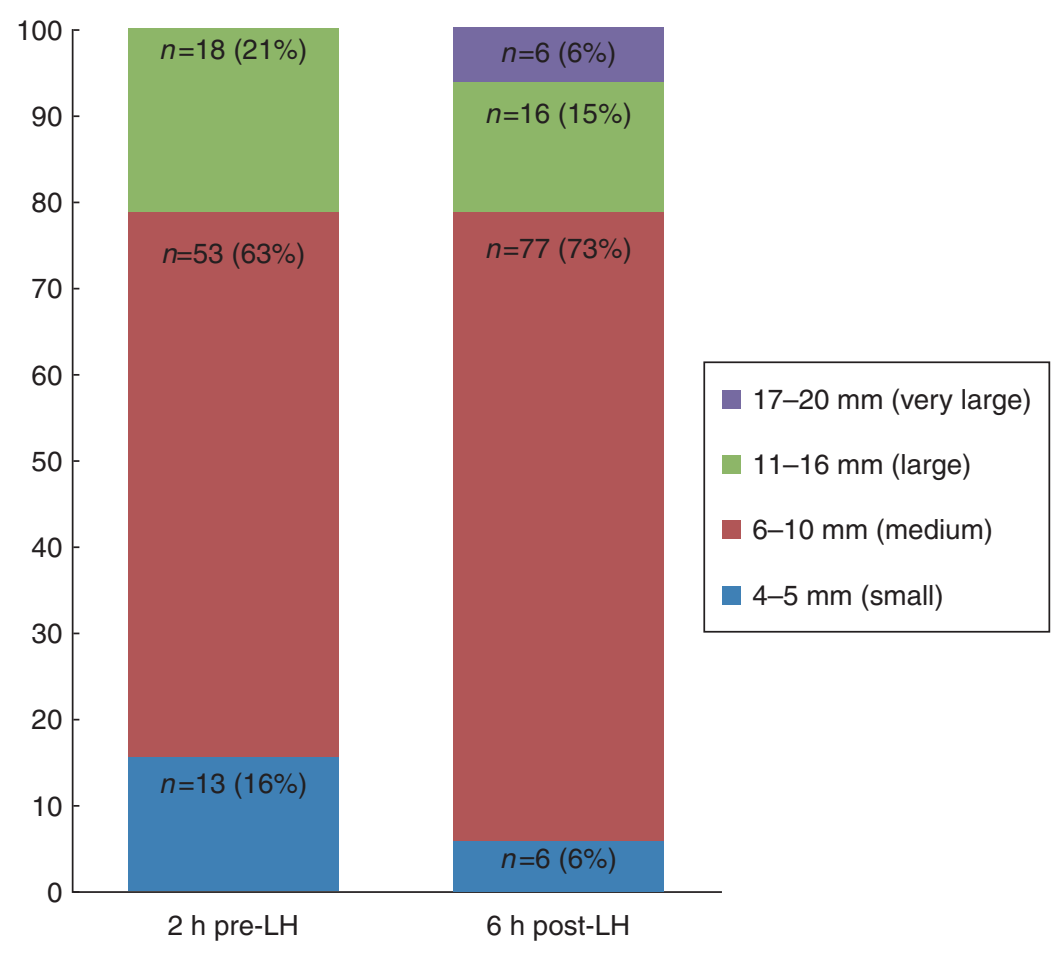

Figure 1 Effect of the $\mathrm{LH}$ surge on follicular size distribution. The number of follicles collected in each size range and their percentage (\%) of the total are indicated. 
A
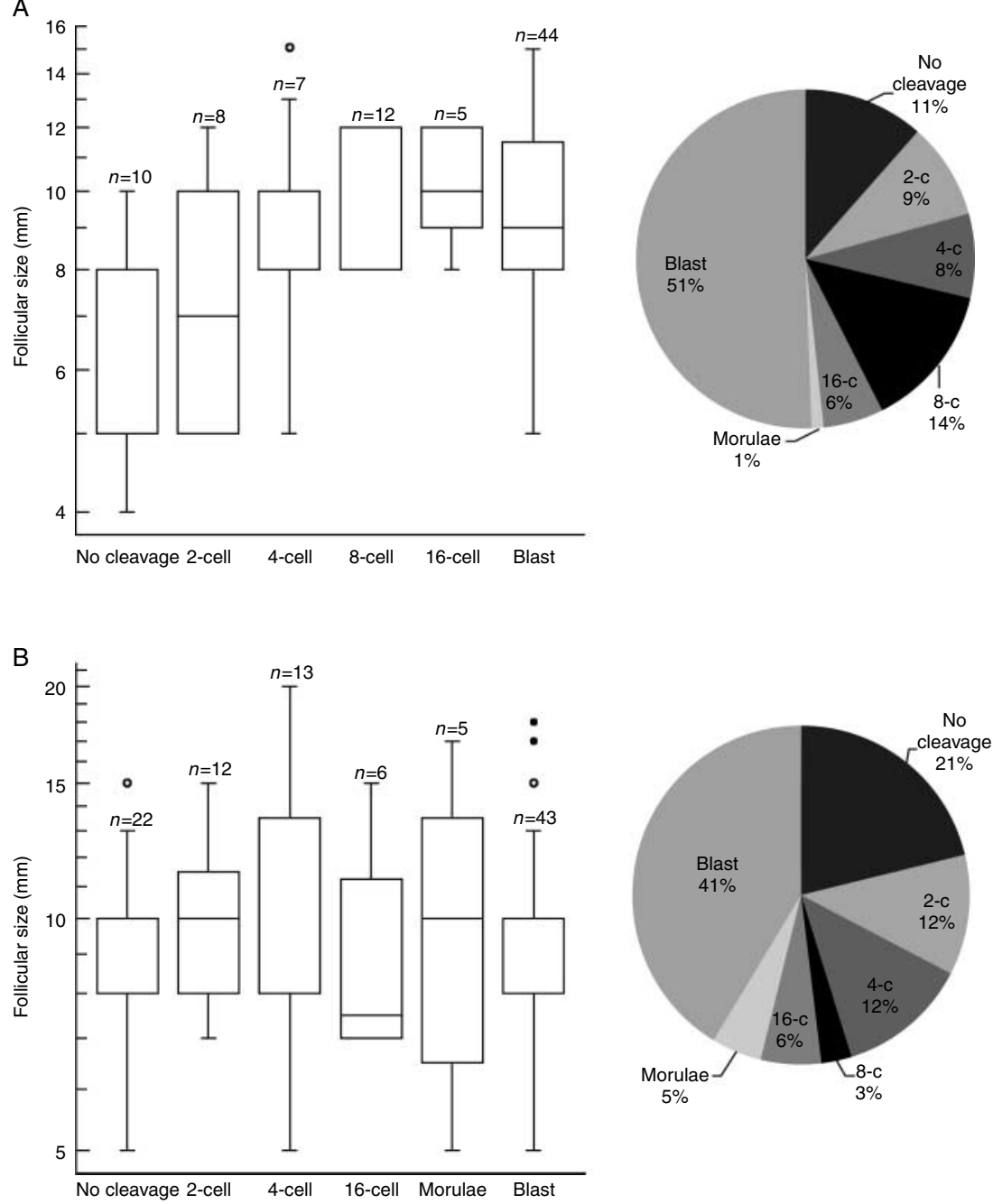

Figure 2 Embryonic development achieved by bovine oocytes obtained from follicles of various sizes. (A) $2 \mathrm{~h}$ before and (B) $6 \mathrm{~h}$ after LH surge. The box plot charts were displayed with log transformed data. The segments inside the boxes are medians and the bars indicate minimum and maximum sizes. Empty circles denote outliers slightly above the third quartile or $1.5 \times$ the interquartile range. Full circles denote outliers at least $3 \times$ above the interquartile range. $n=$ total number of follicles included in each embryonic stage. Empty box $=$ developmental stage with too few data (pre-LH, $n=1$ at the morula stage; post$\mathrm{LH}, n=3$ at the eight-cell stage). Pie charts show the proportions of the embryos that reached each developmental stage.

improve oocyte developmental competence and whether GC isolated from follicles associated with a competent oocyte carry a distinct gene expression profile representative of oocyte quality.

Previous studies have shown that administering $\mathrm{LH}$ produces competent oocytes that are highly likely to undergo normal embryonic development (Blondin et al. 2002, Dieleman et al. 2002, Knijn et al. 2008). In our study, superstimulation with FSH resulted in $52 \%$ of the fertilized oocytes reaching the blastocyst stage, while administering $\mathrm{LH}$ provided $41 \%$ blastocysts. However, blastocyst yield is not the only criterion to evaluate when determining an ovarian stimulation regimen. Embryo quality, which is more likely to be indicative of embryos that will result in a gestation, should also be taken into account. Despite the larger number of blastocysts obtained without LH, blastocyst quality was better with $\mathrm{LH}$. Since the in vivo $\mathrm{LH}$ surge is important for follicle dominance and for the oocyte to reach final maturation, the signal triggered by LH might help follicles, as well oocytes, to acquire important factors necessary for their terminal differentiation, resulting in blastocysts of better quality.

Molecular marker discovery was achieved using our cDNA boutique array (5.7K) built from several subtractive libraries representative of all GC stages. The major advantage of this array is the possibility of identifying transcripts without any a priori selection based on gene function, therefore allowing the discovery of new elements such as novel transcribed regions (NTRs). However, the function of these uncharacterized transcripts remains to be elucidated. Forty differentially expressed transcripts that correlated with oocyte developmental status were found in the pre-LH group. Although the number of total transcripts identified may seem small, a similar study performed in rats using a genome-wide array (30K) identified 13 differentially expressed genes in GC correlated with a competent oocyte (Jiang et al. 2010). Since 'competent' and 'incompetent' GCs are at the same growth stages and are compared with each other, it is not surprising that the differences between these two categories are subtle. 


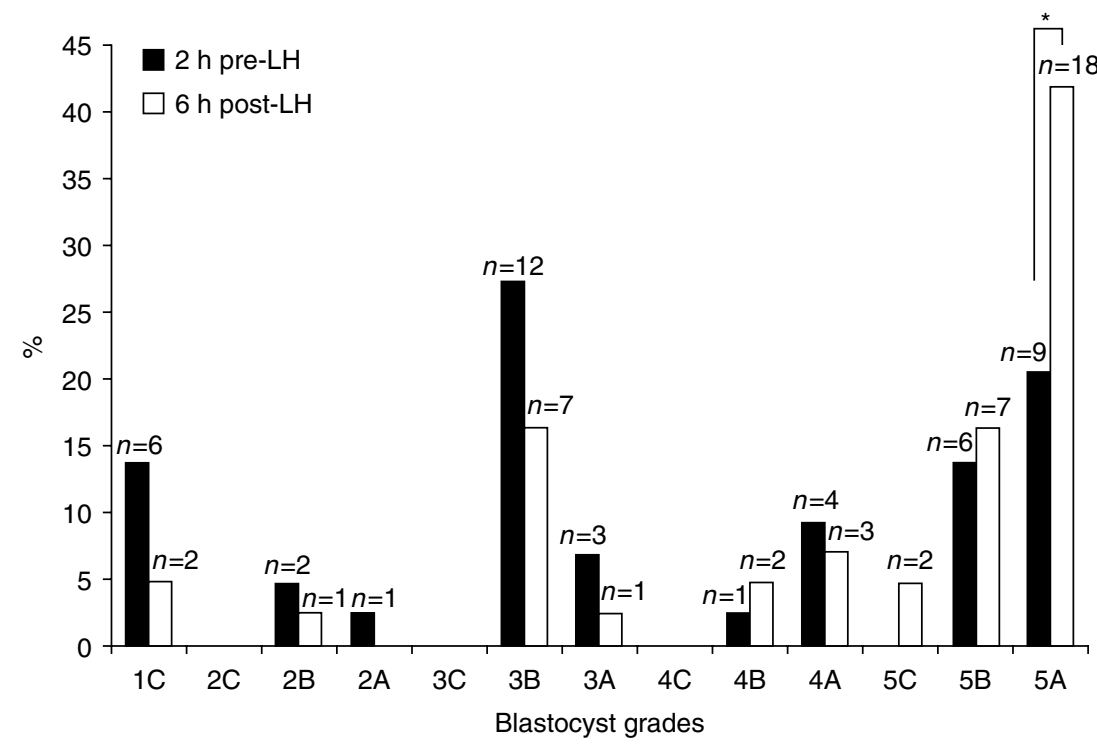

Figure 3 Blastocyst scores for the two stimulation protocols, at day 9 of embryonic development. The number indicates blastocyst development and stage status: 1) early blastocyst (blastocoel cavity less than half the volume of the embryo); 2) young blastocyst (blastocoel cavity more than half the volume of the embryo); 3) blastocyst (cavity completely filling the embryo, with thinning of the zona pellucida); 4) prehatching blastocyst (hatching out of the shell); and 5) hatched blastocyst (hatched out of the shell). The letter indicates inner cell mass and trophectoderm quality: A) very good (many cells tightly packed); B) good (several cells, loosely grouped); C) poor (few cells). *Indicates a statistical difference between the protocols $(P<0.05)$.
The concept of competence refers to the ability of oocytes to develop after fertilization. During folliculogenesis, the oocyte stores the mRNA and proteins that will be required to support subsequent postfertilization development. It has been demonstrated that oocyte transcriptional activity is elevated in the growing follicle until the early antral stages and dramatically decreases afterward (Fair et al. 1997, Memili \& First 1998, Memili et al. 1998). It has thus been proposed that oocyte competence may be acquired before the antral follicle stage (Mermillod et al. 2008). In our results, no molecular marker associated with oocyte competence was found in the post-LH group, while a few were discovered in the pre-LH group. We propose two possible explanations for this phenomenon. The first one is that the new GC transcriptomic program induced by the LH (Gilbert et al. 2011) surge masks differences and variability that might exist between GC associated with good or poor developmental competence in oocytes. The second possibility is that the bidirectional communication between the two cell types is no longer synchronized $6 \mathrm{~h}$ after the LH surge. At this stage, the message sent by the $\mathrm{LH}$ surge induces resumption of meiosis in the oocyte and the expansion of cumulus cells, while GC are preparing for luteinization. The follicular cells and the gamete have undertaken separate differentiation programs to achieve ovulation, suggesting that oocyte competence at this stage is no longer reflected in the GC transcriptional profile.

It this study, GC SERPINE2 was found upregulated in association with competent oocytes. SERPINE2 belongs to the serine protease inhibitor superfamily, modulates the activity of plasminogen activators and is involved in tissue remodeling (Silverman et al. 2001). In cattle, expression of SERPINE2 has been found elevated in dominant follicles and to decrease after the LH surge (Bedard et al. 2003).

For the other markers, no function has been ascribed in the ovary, however their role in other tissues is interesting. For example, SRGN is a proteoglycan stored primarily in the secretory granules of many hematopoietic cells (Abrink et al. 2004). TRIB2 and other members of this family are involved in many physiological processes, such as induction of apoptosis in hematopoietic cells, regulation of inflammatory activation of monocytes, and modulation of gene expression (Hegedus et al. 2007, Eder et al. 2008). Although no precise role in ovarian physiology has been assigned to SRGN and TRIB2, cattle studies indicate upregulation of their mRNA in association with the dominant follicle, decreasing after the LH surge (Ndiaye et al. 2005).

The increased level of INHBA mRNA in GC associated with competent oocytes does not allow us to determine whether the production of inhibin $A$, activin $A$, or $A B$ proteins is altered. Indeed, the INHBA gene nomenclature represents the $\beta A$ subunit and not the dimeric protein. However, during folliculogenesis, activin increases FSH secretion and promotes GC proliferation, while inhibin antagonizes activin by decreasing $\mathrm{FSH}$ secretion. Inhibin can also increase $\mathrm{LH}$-induced thecal androgen synthesis (Hillier 1991, Wrathall \& Knight 1995). In vitro, the presence of activin A in COCs is linked to oocyte developmental competence (Silva \& Knight 1998). These results reflect a pivotal role for the inhibin $\beta A$ (or activin $\beta A$ ) subunit in GC growth and differentiation and in the acquisition of competence by oocytes.

Many of the upregulated markers are associated with chromatin, cell cycle, and DNA stability. For example, ACIN1 was initially found to be activated by caspases and to activate chromatin condensation during apoptosis 


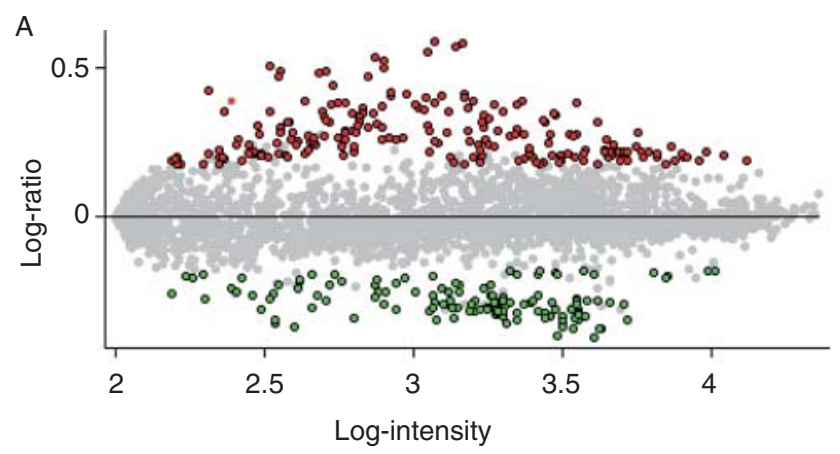

B

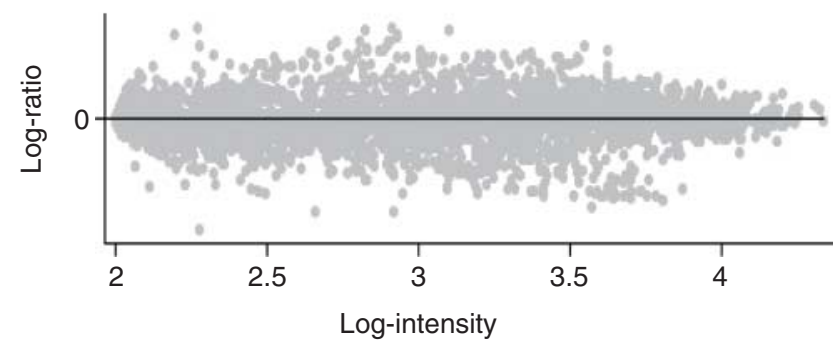

Figure 4 Pairwise comparison of gene expression log mean ratio of competent to incompetent groups of oocytes, obtained by microarray analysis. (A) $2 \mathrm{~h}$-pre-LH protocol and (B) $6 \mathrm{~h}$-post-LH protocol.

Horizontal axis represents log average intensity and the vertical axis represents log signal intensity ratio of competent to incompetent groups for each clone. The red spots represent overexpressed clones and green spots represent underexpressed clones, using a 1.5-fold-change filter with FDR $\leq 0.05$.

(Joselin et al. 2006). Other roles in mRNA processing and spliceosomes have also been attributed to this factor and its knockdown has been shown to lead to a decrease in cell growth (Rappsilber et al. 2002, Zhou et al. 2002, Joselin et al. 2006). The mitotic checkpoint component Mad2 (MAD2) is a component of the spindle checkpoint (Musacchio \& Hardwick 2002) for mitotic cells, oocytes need MAD2 in order to bring about meiosis 1 arrest (Homer et al. 2005). So far, little is known about calmodulin-binding transcription activator 1 (CAMTA1), but it has been demonstrated that its mRNA levels in neuroblastoma cells can be high during the $S$ and $\mathrm{M}$ phases and decrease after mitosis (Nakatani et al. 2004). Single-stranded DNA binding protein 1 (SSCBP1) is essential for the response to DNA damage, and with the help of Integrator3 protein, it controls $\mathrm{G}(2) / \mathrm{M}$ checkpoint activation (Zhang et al. 2009). Replication protein A3 (RPA3), like SSCBP1, is also a single-stranded DNA-binding protein and plays a central role in many aspects of nucleic acid metabolism, including DNA replication, repair, and recombination (Salas et al. 2009, Mason et al. 2010). Proliferating cells are challenged with maintenance of genome integrity and chromatin organization in order to avoid aberrant gene expression. Since chromatin is involved in many events, including transcription, replication, repair, and recombination, cells have developed mechanisms such as cell cycle checkpoints to avoid defects in replication or in mitotic spindle assembly (reviewed by Koundrioukoff et al. (2004)). In the present study, the implication of markers involved in genome stability and in cell cycle checkpoints is interesting since GC at this stage (i.e. before the LH surge) seems to be growing and proliferating actively due to FSH administration. The majority of the molecular markers found in this study seem to be involved in chromatin integrity and cell cycle checkpoints, which are essential for GC proliferation and follicular differentiation (through dominance acquisition) in order to achieve preovulation status and ultimately ovulation.

From pathway analyses, two networks were identified using upregulated and downregulated molecular markers associated with oocyte developmental competence. The network linking the overexpressed transcripts is involved in lipid metabolism, molecular transport, and small molecule biochemistry. The transcripts of two enzymes involved in lipid metabolism were thus identified, namely stearoyl-CoA desaturase (SCD) and MSMO1. SCD is involved in unsaturated fatty acid synthesis and therefore influences cell membrane fluidity (Zhang et al. 1999). It has also been involved in membrane organization and depletion of a specific pool of membrane cholesterol, thereby increasing intracellular cholesterol bioavailability (Sun et al. 2003). The MSMO1 enzyme also plays a role in cholesterol biosynthesis. In BMP15 GDF9 double-mutant mice, cumulus cell transcripts involved in cholesterol synthesis, including MSMO1 are reduced before the LH surge (Su et al. 2008). These results show that the oocyte cannot synthesize cholesterol and relies on follicular cells to provide the enzyme required for cholesterol synthesis (Su et al. 2008). GC acquires a high level of steroidogenic potential after the LH surge and it therefore appears that the enzymes required for cholesterol biosynthesis must be present.

In summary, the data presented in this study show that GC transcripts may be markers of the ability of oocytes to proceed through the early stages of embryonic development. Cattle are highly suitable for this type of study, since it is possible to examine the preovulation period, the moment at which differences in oocyte competence may be decisive. It thus appears that the right time to solve the competence puzzle is before the LH surge. Better knowledge of the molecular markers involved in oocyte competence will increase the success of ovarian stimulation and subsequent embryo production and will allow the identification of important metabolic pathways for functions that remain to be resolved.

\section{Materials and Methods}

\section{Ovarian stimulation and GC collection}

Twelve cows at mid-cycle were treated using an intravaginal progesterone-releasing device to prevent premature $\mathrm{LH}$ surge 
Table 2 Differential expression of RNA transcripts by GCs associated with competent vs incompetent oocytes under the 2 h-pre-LH stimulation protocol.

\begin{tabular}{|c|c|c|c|c|}
\hline Gene & Symbol & Accession no. & $\begin{array}{c}\text { Relative } \\
\text { expression }\end{array}$ & $\begin{array}{l}\text { Redundancy } \\
\text { factor }\end{array}$ \\
\hline \multicolumn{5}{|c|}{ Overexpressed transcripts in the $2 \mathrm{~h}$ pre-LH group (more expressed in GC associated with competent oocyte) } \\
\hline Apoptotic chromatin condensation inducer 1 & ACIN1 & NM_001105410 & 1.78 & 1 \\
\hline ATP synthase, $\mathrm{H}+$ transporting, mitochondrial F1 complex & ATP5A1 & BC116059 & 1.58 & 2 \\
\hline Inhibin, beta A & INHBA & NM_174363 & 1.78 & 4 \\
\hline Mitotic checkpoint component Mad2 & MAD2 & NM_001079796 & 1.52 & 1 \\
\hline Phosphatidylethanolamine binding protein & PEBP1 & NM_001033623 & 1.60 & 1 \\
\hline Replication protein A3 & RPA3 & NM_001034427 & 1.63 & 4 \\
\hline Serglycin & SRGN & NM_001025326 & 2.05 & 35 \\
\hline Serpin peptidase inhibitor, clade $\mathrm{E}$ member 2 & SERPINE2 & NM_174669 & 1.55 & 5 \\
\hline Single-stranded DNA binding protein & SSBP1 & NM_001037466 & 1.68 & 1 \\
\hline Stearoyl-CoA desaturase & $S C D$ & NM_173959 & 1.52 & 2 \\
\hline Sterol-C4-methyl oxidase-like & MSMO1 & NM_001098863 & 1.83 & 2 \\
\hline Tribbles homolog 2 & TRIB2 & NM_178317 & 1.81 & 6 \\
\hline Predicted: calmodulin-binding transcription activator 1 & CAMTA1 & XM_610833 & 1.65 & 2 \\
\hline Predicted: mCG1035404-like & HNRNPA3 & XM_002685299 & 1.64 & 1 \\
\hline Novel transcribed region 1 & Unassigned & & 1.68 & 3 \\
\hline Novel transcribed region 2 & Chr4 & & 1.99 & 53 \\
\hline Novel transcribed region 3 & Chr19 & & 1.55 & 1 \\
\hline Novel transcribed region 4 & Chr3 & AB047862 & 1.70 & 6 \\
\hline \multicolumn{5}{|c|}{ Underexpressed transcripts in the $2 \mathrm{~h}$ pre-LH group (more expressed in GC associated with incompetent oocyte) } \\
\hline Annexin A4 & ANXA4 & NM_001001440 & -1.54 & 1 \\
\hline $\begin{array}{l}\text { Cytochrome } c \text {, somatic nuclear gene encoding mitochondrial } \\
\text { protein }\end{array}$ & CYCS & NM_001046061 & -1.78 & 2 \\
\hline Mediator complex subunit 21 & MED21 & NM_001038566 & -1.64 & 1 \\
\hline Mitochondrial DNA & & $\mathrm{HM} 045018$ & -2.03 & 146 \\
\hline Ribosomal protein L13a & RPL13A & NM_001076998 & -2.10 & 1 \\
\hline Ribosomal protein L18 & RPL18 & NM_001015556 & -1.50 & 1 \\
\hline Ribosomal protein L36 & RPL36 & NM_001078139 & -1.58 & 2 \\
\hline Ribosomal protein L7a & RPLTA & NM_001040520 & -2.01 & 2 \\
\hline Ribosomal protein S13 & RPS13 & NM_001025342 & -1.51 & 1 \\
\hline Ribosomal protein S20 & RPS2O & NM_001034438 & -1.53 & 1 \\
\hline Secreted protein, acidic, cysteine-rich & SPARC & NM_174464 & -1.85 & 7 \\
\hline Selenoprotein $\mathrm{K}$ & SELK & NM_001037489 & -1.52 & 1 \\
\hline Solute carrier family 38, member 2 & SLC38A2 & NM_001082424 & -2.18 & 1 \\
\hline Steroidogenic acute regulatory protein & STAR & NM_174189 & -2.26 & 1 \\
\hline Thymosin beta $4, \mathrm{X}$-linked & $T M S B 4 X$ & NM_001002885 & -1.59 & 2 \\
\hline Tumor necrosis factor, alpha-induced prot 6 & TNFAIP6 & NM_001007813 & -2.57 & 2 \\
\hline Tumor protein, translationally-controlled 1 & TPT1 & NM_001014388 & -1.51 & 1 \\
\hline Novel transcribed region 5 & Unassigned & & -1.78 & 26 \\
\hline Novel transcribed region 6 & Chr17 & & -1.66 & 1 \\
\hline Novel transcribed region 7 & Chr18 & & -1.82 & 1 \\
\hline Novel transcribed region 8 & Chr26 & & -1.83 & 1 \\
\hline Novel transcribed region 9 & Chr5 & & -2.10 & 4 \\
\hline
\end{tabular}

(CIDR; Pfizer Canada Inc., Saint-Laurent, QC, Canada) for 7 days. On day 1 AM, dominant follicle was punctured using transvaginal ultrasonography (3 days after insertion of the device). Follicular growth was initiated by injection of $\mathrm{FSH}$ (FollTropin-V; Bioniche Animal Health, Belleville, ON, Canada) in decreasing doses at $12 \mathrm{~h}$ intervals over the next 5 days (day 2 PM: 70 mg; day 3 AM/PM: 60 mg; day 4 AM/PM: $50 \mathrm{mg}$; day 5 AM/PM: $40 \mathrm{mg}$; and day $6 \mathrm{AM}: 30 \mathrm{mg}$; for a total of $400 \mathrm{mg}$ of $\mathrm{NIH}-\mathrm{FSH}-\mathrm{PI})$. Two milliliters of prostaglandin $\mathrm{F} 2 \mathrm{a}$ (Estrumate; Intervet Canada Corp., Kirkland, QC, Canada) containing $500 \mu \mathrm{g}$ of cloprostenol were injected $12 \mathrm{~h}$ before (day 4 PM) and after (day 5 AM) the removal of the progesterone device (day 5 AM). LH (25 mg of Lutropin-V; Bioniche Animal Health) was administered $12 \mathrm{~h}$ after the final FSH injection (day 6 PM). Ovariectomies were done either $2 \mathrm{~h}$ before this (pre-LH group) or $6 \mathrm{~h}$ after (post-LH group). Ovaries were transported without delay to the laboratory in $0.9 \% \mathrm{NaCl}$ at $37^{\circ} \mathrm{C}$. COC from all follicles $>4 \mathrm{~mm}$ were removed by aspiration and utilized for the IVP. Then, follicles were cut and turned inside out and GCs were scrapped off in a small volume of PBS and centrifuged. The supernatant was removed and the GC pellet was placed in RNAlater solution (Applied Biosystems, Streetville, ON, Canada) and frozen at $-20^{\circ} \mathrm{C}$ until RNA extraction.

\section{COC pooling}

Previous experiments have indicated that cultured bovine oocytes develop better in groups than individually (data not shown). We therefore pooled oocytes, of the same cow, from 
A
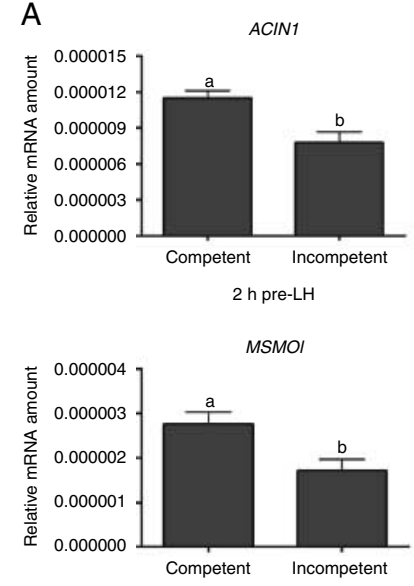

$2 \mathrm{~h}$ pre-LH
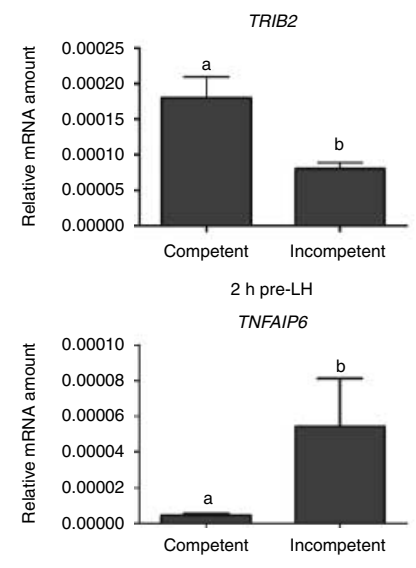

$2 \mathrm{~h}$ pre-LH
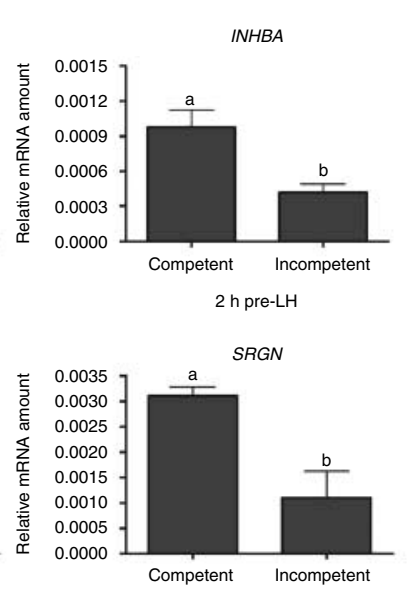

$2 \mathrm{~h}$ pre-LH

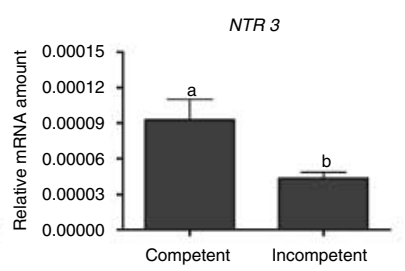

$2 \mathrm{~h}$ pre-LH
B
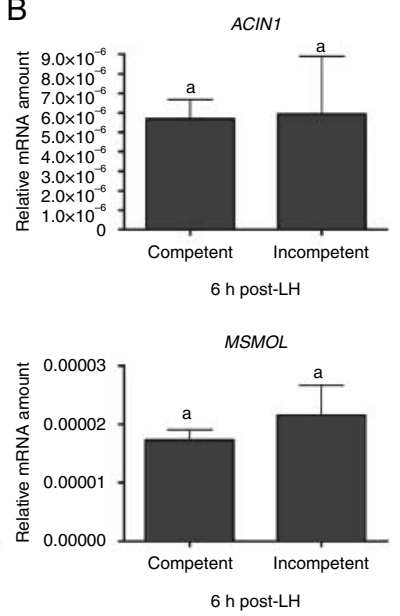

TRIB2

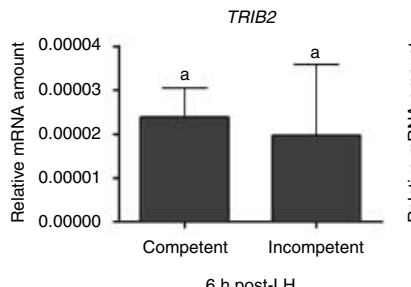

$$
6 \mathrm{~h} \text { post-LH }
$$

TNFAIP6

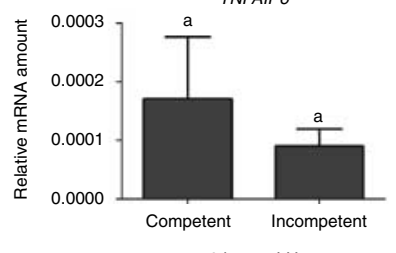

$6 \mathrm{~h}$ post-LH

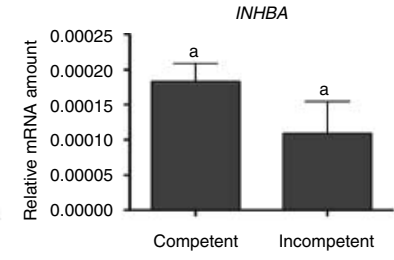

$6 \mathrm{~h}$ post-LH

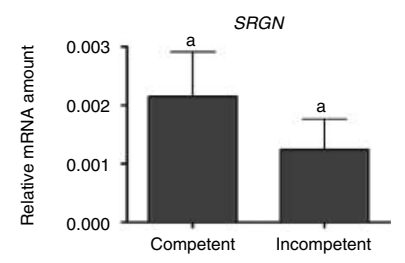

$6 \mathrm{~h}$ post-LH

NTR 3

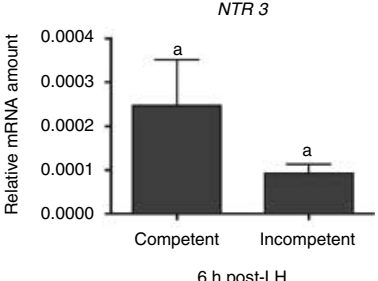

Figure 5 Quantitative RT-PCR. Reactions were performed in triplicate with nonamplified cDNA in the (A) 2 h-pre-LH and (B) 6 h-post-LH. Differing letters indicate significant differences. Overexpressed markers: ACIN1, apoptotic chromatin condensation inducer 1; INHBA, inhibin beta A; MSMO1, sterol-C4-methyl oxidase-like; SRGN, serglycin; TRIB2, tribbles homolog 2; NTR3, novel transcribed region 3, and underexpressed marker: TNFAIP6, tumor necrosis factor alpha-inducible protein 6.

follicles of similar size into groups of three and monitored their development up to the blastocyst stage. This pooling also decreases the impact of individual variations, which are not of interest, and therefore increases the chance of identifying reliable markers of competence by group contrast.

\section{Oocyte maturation and in vitro production}

COCs were placed in HEPES-buffered Tyrode's medium (THL) supplemented with $10 \%$ bovine serum, $200 \mu \mathrm{M}$ pyruvate and $50 \mu \mathrm{g} / \mathrm{ml}$ gentamicin). Group of three COC was placed in $50 \mu \mathrm{l}$ droplets of medium under $9 \mathrm{ml}$ of filtered mineral oil. Maturation medium was composed of TCM199 (Gibco 11150-059; Invitrogen), 10\% FCS (Sterile Foetal Bovine Serum for cell Culture; Medicorp, Montreal, QC, Canada), $200 \mu \mathrm{M}$ pyruvate, $50 \mu \mathrm{g} / \mathrm{ml}$ gentamicin with $50 \mu \mathrm{g} / \mathrm{ml}$ of porcine LH (pLH; Lutropin-V, Bioniche Animal Health), $0.5 \mu \mathrm{g} / \mathrm{ml}$ porcine FSH (pFSH; Folltropin-V), and $1 \mathrm{mg} / \mathrm{ml}$ of estradiol-17b (Sigma-Aldrich Canada Ltd). Droplets containing COCs were incubated for $24 \mathrm{~h}$ at $38.5^{\circ} \mathrm{C}$ in a humidified $5 \%$ $\mathrm{CO}_{2}, 20 \% \mathrm{O}_{2}$ atmosphere.
Fertilization was then carried out using thawed bovine semen (Centre $d^{\prime}$ 'insemination artificielle du Quebec) and fertilization medium consisting of modified Tyrode-lactate medium with fatty acid-free BSA, pyruvic acid, gentamicin, heparin (final concentration, $2 \mu \mathrm{g} / \mathrm{ml}$ ), and penicillamine, hypotaurine, and epinephrine. Fertilization took place during $15-18 \mathrm{~h}$ of incubation at $38.5^{\circ} \mathrm{C}$ in a humidified $5 \% \mathrm{CO}_{2}, 20 \%$ $\mathrm{O}_{2}$ atmosphere. The fertilized oocytes were then cocultured in group of three in 50- $\mu$ l drops with Buffalo Rat Liver (BRL) cells in Ménézo's B2 medium (Meditech Canada, Inc., Montreal, QC, Canada) with $0.4 \%$ fatty acid-free BSA and then transferred to other droplets containing B2-BRL and $10 \%$ estrus cow serum in humidified atmosphere containing $5 \%$ $\mathrm{CO}_{2}$. Embryos were transferred $96 \mathrm{~h}$ postfertilization to fresh droplets of B2-BRL with $20 \%$ estrous cow serum. On day 9 of culture, embryos were graded according to the criteria of the International Embryo Transfer Society (Robert \& Nelson 1998). To be assigned to the competent group, the three oocytes of the same droplets had to reach the blastocyst stage. To be designated to the incompetent group, the three oocytes of the same droplets had led to three developmental arrests. 

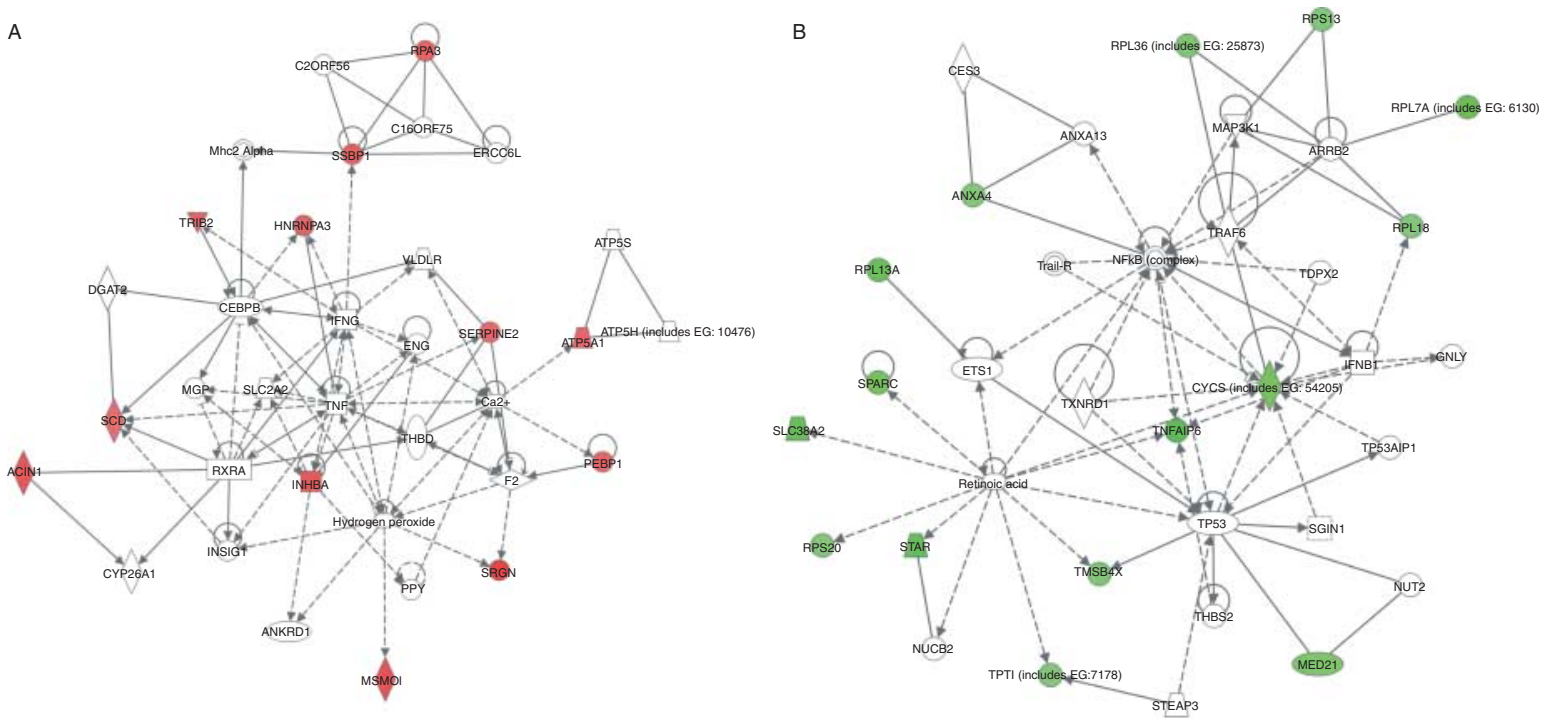

Figure 6 Network of interactions among markers found in the 2 h-pre-LH group, based on microarray analysis. (A) Genes found upregulated: ACIN1, apoptotic chromatin condensation inducer 1 ; ANKRD1, ankyrin repeat domain 1; ATP5J, ATP synthase; CEBPB, CCAAT/enhancer binding protein (C/EBP) beta; CYP26A1, cytochrome P450 family 26 subfamily A polypeptide 1; DGAT2, diacylglycerol O-acyltransferase 2; ENG, endoglin; $M G P$, matrix Gla protein; $E R C C 6 L$, excision repair cross-complementing rodent repair deficiency complementation group 6-like; HNRNPA3, heterogeneous nuclear ribonucleoprotein A3; IFNG, interferon gamma; INHBA, inhibin beta A; F2, coagulation factor II (thrombin); INSIG1, insulin induced gene 1; CIITA, major histocompatibility complex class 2; $P E B P 1$, phosphatidylethanolamine binding protein 1; $P P Y$, pancreatic polypeptide; $R P A 3$, replication protein $\mathrm{A} 3$; $R X R A$, retinoid X receptor alpha; $S C D$, stearoyl-CoA desaturase; MSMO1, sterol-C4-methyl oxidase-like; SLC2A2, solute carrier family 2 member 2; SRGN, serglycin; SSBP1, single-stranded DNA binding protein; $T H B D$, thrombomodulin; $T N F$, tumor necrosis factor; TRIB2, tribbles homolog 2; and $V L D L R$, very low density lipoprotein receptor. (B) Genes found downregulated: $A N X A 13$, annexin A13; $A R R B 2$, arrestin beta 2; CES3, carboxylesterase 3; CYCS, cytochrome $c$ somatic; ETS1, v-ets erythroblastosis virus E26 oncogene homolog 1; GNLY, granulysin; SLC38A2, solute carrier family 38 member 2, IFNB1, interferon, beta 1 fibroblast; MAP3K1, mitogen-activated protein kinase 1; MED21, mediator complex subunit 21; NFKB, nuclear factor of kappa light polypeptide gene enhancer in B-cells; NUCB2, nucleobindin 2; MED10, mediator complex subunit 10 (MED10); OSGIN1, oxidative stress induced growth inhibitor 1; RPL7A, ribosomal protein L7a; RPL13A, ribosomal protein L13a; $R P L 18$, ribosomal protein L18; RPS13, ribosomal protein S13; RPS20, ribosomal protein S20; RPL36, ribosomal protein L36, SPARC, secreted protein acidic cysteine-rich; STAR, steroidogenic acute regulatory protein; STEAP3, STEAP family member 3 metalloreductase; TDPX2, thioredoxindependent peroxide reductase 2; THBS2, thrombospondin 2; TMSB4X, thymosin beta 4 X-linked; TNFAIP6, tumor necrosis factor alpha-induced protein 6; TP53, tumor protein p53; TP53AIP1, tumor protein p53 regulated apoptosis inducing protein 1; TPT1, tumor protein translationallycontrolled 1; TRAF6, TNF receptor-associated factor 6; TNFRSF10B, tumor necrosis factor receptor superfamily member 10b; and TXNRD1, thioredoxin reductase 1 . Uncolored nodes represent eligible molecules provided by the Ingenuity knowledge base to maximize connectivity.

\section{Statistical analysis}

To assess the effect of the LH surge on follicle size, a linear mixed model was used. To assess the effect of the LH surge on blastocyst production, a generalized estimating equations (GEE) model was used with a logit link. To assess the effect of the LH surge on blastocyst scores at day 9, GEE models with a generalized logit link were used. In every case, correlation between observations for the same cow was taken into account, using a random effect in the linear mixed model and using a sandwich estimator in the GEE models. The normality criterion of the linear mixed model was not met. A log transformation was applied to follicle size in order to meet the normality criterion. Since both the model applied to transformed data and the one applied to untransformed data yielded the same conclusions, only the results obtained using the untransformed data were interpreted.

\section{GC selection}

The GC molecular marker investigation was done using comparison within ovarian stimulation protocols (i.e. pre-LH or post-LH). Microarray comparisons were performed with three biological replicates, from three different cows, for each GC categories, e.g. three 'competents' vs three 'incompetents' for the pre-LH group and three 'competents' vs three 'incompetents' for the post-LH groups (for a total of 12 groups). For each stimulation protocol, GCs associated with 'competent' oocytes were compared with those associated with 'incompetent' oocytes. GCs were deemed 'competent' only when all three oocytes in a droplet yielded a blastocyst. GCs were deemed 'incompetent' when three developmental arrests were noted (Table 3).

\section{Total RNA extraction}

Total RNA extracted from each pool (three follicles) of GC using the Absolutely RNA Miniprep Kit (Stratagene, LaJolla, CA, USA) was recovered in a $30-\mu$ l elution volume using the provided buffer. The RNA extraction procedure included an on-column DNase I treatment to remove genomic DNA. Total RNA integrity and concentration were evaluated using the 2100Bioanalyzer (Agilent Technologies, Palo Alto, CA, USA) with the RNA NanoLab Chip (Agilent Technologies). 
Table 3 Description of the samples used for microarray hybridizations.

\begin{tabular}{|c|c|c|c|c|}
\hline Treatment & Group & $\begin{array}{c}\text { Follicle } \\
\text { size }(\mathrm{mm})\end{array}$ & $\begin{array}{l}\text { Stage } \\
\text { reached }\end{array}$ & $\begin{array}{l}\text { Blastocyst } \\
\text { score }\end{array}$ \\
\hline \multirow[t]{18}{*}{2 h-pre-LH } & \multirow[t]{9}{*}{ Competent } & 6 & Blast & $3 B$ \\
\hline & & 6 & Blast & $3 B$ \\
\hline & & 6 & Blast & $3 B$ \\
\hline & & 8 & Blast & $5 \mathrm{~A}$ \\
\hline & & 8 & Blast & $4 \mathrm{~A}$ \\
\hline & & 8 & Blast & $2 \mathrm{~B}$ \\
\hline & & 8 & Blast & $5 \mathrm{~A}$ \\
\hline & & 8 & Blast & $5 \mathrm{~A}$ \\
\hline & & 8 & Blast & $5 \mathrm{~A}$ \\
\hline & \multirow[t]{9}{*}{ Incompetent } & 12 & 16-cell & NA \\
\hline & & 12 & 8-cell & NA \\
\hline & & 12 & 2-cell & NA \\
\hline & & 10 & 16-cell & NA \\
\hline & & 10 & 16-cell & NA \\
\hline & & 10 & 2 -cell & NA \\
\hline & & 8 & 4-cell & NA \\
\hline & & 8 & 4-cell & NA \\
\hline & & 8 & No cleavage & NA \\
\hline \multirow{18}{*}{6 h-post-LH } & \multirow[t]{9}{*}{ Competent } & 10 & Blast & $5 \mathrm{~A}$ \\
\hline & & 10 & Blast & $4 \mathrm{~A}$ \\
\hline & & 10 & Blast & $3 B$ \\
\hline & & 10 & Blast & $5 \mathrm{~A}$ \\
\hline & & 10 & Blast & $5 \mathrm{~A}$ \\
\hline & & 10 & Blast & $5 \mathrm{~A}$ \\
\hline & & 10 & Blast & $5 B$ \\
\hline & & 10 & Blast & $5 \mathrm{~A}$ \\
\hline & & 10 & Blast & $3 B$ \\
\hline & \multirow[t]{9}{*}{ Incompetent } & 15 & 16-cell & NA \\
\hline & & 15 & 16-cell & NA \\
\hline & & 15 & No cleavage & NA \\
\hline & & 8 & 16-cell & NA \\
\hline & & 8 & 4-cell & NA \\
\hline & & 8 & 2-cell & NA \\
\hline & & 10 & 4-cell & NA \\
\hline & & 10 & 2-cell & NA \\
\hline & & 10 & No cleavage & NA \\
\hline
\end{tabular}

NA, not applicable.

\section{Custom-made cDNA microarray slide conception}

Results obtained by many researchers have demonstrated the value of combining cDNA arrays with subtractive suppressive hybridization $(\mathrm{SSH})$ to increase the probability of identifying genes of interest (Hamel et al. 2008). A boutique microarray representative of all GC stages in bovine follicles was therefore generated using the $\mathrm{SSH}$ technique. Five ovarian combinations, namely $6 \mathrm{~h}$-post-LH vs $<3-\mathrm{mm}$ follicles and its reverse ( $<3 \mathrm{~mm}$ vs 6 h-post-LH), $2 \mathrm{~h}$-pre-LH vs preovulatory follicle (e.g. $22 \mathrm{~h}$-post-LH) and its reverse $(22 \mathrm{~h}$-post-LH vs $2 \mathrm{~h}$ pre-LH), and finally 6 h-post-LH 'competent' vs 6 h-post-LH 'incompetent' follicles thus provided cDNA. Briefly, the SSH was performed using pools of $1 \mu \mathrm{g}$ of total RNA. The mRNAs were reverse transcribed and the cDNAs were amplified using the BD SMART PCR cDNA Synthesis Kit (BD Biosciences, Mississauga, ON, Canada) according to the manufacturer's instructions. The SSH was performed with the PCR Select cDNA Subtraction Kit (BD Biosciences) as described by the manufacturer. The subtracted PCR products generated by SSH were cloned into the pGEM-T easy vector systems (Promega) and then transformed into One-shot max efficiency DH5 $\alpha$-T1 competent cells (Invitrogen). For each library, 1152 clones were randomly selected for PCR amplification. The PCR products of 5760 randomly selected clones were purified using UNIFILTER 384-well purification plates (Whatman Inc., Clifton, NJ, USA) according to the manufacturer's instructions. Purified PCR products were speedvac-evaporated (SPD SpeedVac ThermoSavant, Fisher Scientific Limited, Nepean, ON, Canada), resuspended in a mixture of equal parts of $3 \times$ SSC $(1 \times$ SSC: $0.15 \mathrm{M}$ sodium chloride and $0.015 \mathrm{M}$ sodium citrate with dimethyl sulfoxide), and spotted in two replicates on GAPS II glass slides (Corning, Corning, NY, USA) using a VersArray Chip Writer Pro Robot (Bio-Rad). Slides were then cross-linked with u.v. according to the manufacturer's instructions. Quality control experiments were performed after each set of slides with TOTO-1 dye (Molecular Probe, Burlington, ON, Canada) and Terminal Transferase dye (Roche Diagnostics).

\section{Sample labeling, hybridization, and microarray scanning}

Five hundred nanograms of total RNA from 12 pools of 2 h-preLH and 6 h-post-LH were amplified using T7 RNA polymerase (Arcturus RiboAmp PLUS; Life Technologies Inc., Burlington, ON, Canada) according to the manufacturer's indications. A fixed amount of $2.5 \mu \mathrm{g}$ aRNA was labeled indirectly using ULS aRNA Fluorescent Labeling (Kreatech Biotechnology, Amsterdam, The Netherlands) according to the manufacturer's protocol. Labeling efficiency was measured using the NanoDrop ND-1000 (NanoDrop Technologies, Wilmington, DE, USA). Three biological replicates were used for each GC stage with a technical dye swap replicate. Six hybridizations for each treatment (total of 12 hybridizations) were performed in a dye swap design and hybridized on the cDNA boutique arrays.

Hybridizations were performed in SlideHyb buffer \#1 (Ambion, Austin, TX, USA) at $55^{\circ} \mathrm{C}$ for $18 \mathrm{~h}$ in the SlideBooster hybridization station (Advalytix, San Francisco, CA, USA). Slides were then washed twice with $2 \times$ SSC- $0.5 \%$ SDS at $55{ }^{\circ} \mathrm{C}$ for $15 \mathrm{~min}$ and twice with $0.5 \times$ SSC-0.5\% SDS at $55{ }^{\circ} \mathrm{C}$ for $15 \mathrm{~min}$. The slides were dipped three times in $1 \times$ SSC and three times in $\mathrm{H}_{2} \mathrm{O}$. Finally, the slides were dried by centrifugation at $1200 \mathrm{~g}$ at room temperature for $5 \mathrm{~min}$.

Slides were scanned using the VersArray ChipReader System (Bio-Rad) and visualized with the ChipReader software (Media Cybernetics, San Diego, CA, USA). After acquisition, scanned images were analyzed using ArrayPro Analyzer software (Media Cybernetics).

\section{Microarray data normalization and statistical analysis}

Signal intensity data files were normalized using ArrayPro software (Media Cybernetics). In the preprocessing step, the background of the intensity files was removed using Minimum Background Subtraction. Data were transformed in $\log _{2}$ and normalized for dye bias using a within-array loess.

To identify upregulated and downregulated genes, normalized data were assessed using NIA array analysis software (http://Igsun.grc.nia.nih.gov/ANOVA). A cutoff threshold on minimum log intensity was first applied to the data and this threshold was determined using the average log 
Table 4 Primer sequences used for real-time PCR validation.

\begin{tabular}{|c|c|c|c|c|c|c|}
\hline Gene & Forward sequence & Reverse sequence & $\begin{array}{l}\text { Annealing } \\
\text { temp }\left({ }^{\circ} \mathrm{C}\right)\end{array}$ & $\begin{array}{c}\text { Fluorescence } \\
\text { acquisition } \\
\text { temp }\left({ }^{\circ} \mathrm{C}\right)\end{array}$ & $\begin{array}{l}\text { Product } \\
\text { size }(b p)\end{array}$ & Accession number \\
\hline ACIN1 & $5^{\prime}$-ctcagtagaggtggccttgc-3' & $5^{\prime}$-cctaaagtgaagggacgaacc-3' & 57 & 85 & 216 & NM_001105410 \\
\hline HPRT1 $^{\mathrm{a}}$ & $5^{\prime}$-ggctcgagatgtgatgaagg-3' & $5^{\prime}$-gcaaagtctgcattgtcttcc- $3^{\prime}$ & 57 & 83 & 293 & NM 001034035 \\
\hline INHBA & $5^{\prime}$-gaagggaagaagagggatgg- $3^{\prime}$ & $5^{\prime}$-agtcattccagccaatgtcc- $3^{\prime}$ & 57 & 89 & 208 & NM_174363 \\
\hline SRGN & $5^{\prime}$-cagtgcaatcctgacagtcc- $3^{\prime}$ & $5^{\prime}$-tctgctccagaacctgatcc- $3^{\prime}$ & 57 & 82 & 197 & NM_001025326 \\
\hline MSMO1 & $5^{\prime}$-agctttaagggccattttgc- $3^{\prime}$ & $5^{\prime}$-ttcaataggaggccaacacc- $3^{\prime}$ & 57 & 78 & 176 & NM_001098863 \\
\hline NTR3 & $5^{\prime}$-tctctgctctccctcaatcc- $3^{\prime}$ & $5^{\prime}$-cctccacctcaaagttgtcc- $3^{\prime}$ & 57 & 79 & 181 & Unknown \\
\hline TNFAIP6 & $5^{\prime}$-caagggcagagttggatacc-3' & $5^{\prime}$-tgtgccagtagcagatttgg-3' & 57 & 81 & 230 & BC151789 \\
\hline TRIB2 & $5^{\prime}$-gtggcatgtatgtgcagacc- $3^{\prime}$ & $5^{\prime}$-acaggacaaagcaccagagg- $3^{\prime}$ & 57 & 84 & 300 & NM_178317 \\
\hline$Y W H A Z^{\mathrm{a}}$ & $5^{\prime}$-ccagtcacagcaagcatacc-3' & $5^{\prime}$-cttcagcttcgtctccttgg-3 $3^{\prime}$ & 57 & 82 & 287 & NM_174814 \\
\hline
\end{tabular}

ACIN1, apoptotic chromatin condensation inducer 1; HPRT1, hypoxanthine phosphoribosyltransferase 1; INHBA, inhibin beta A; SRGN, serglycin; MSMO1, sterol-C4-methyl oxidase-like; NTR3, novel transcribed region 3; TRIB2, TRB-2 protein; and YWHAZ, tyrosine 3-monooxygenase/ tryptophan 5-monooxygenase.

a Housekeeping genes used for data normalization.

intensity of the negative controls present on the slide. All probes with an increase $>1.5$ and false-discovery rate (FDR) value $<0.05$ were deemed differentially expressed.

\section{DNA sequencing and clone identification}

After microarray analysis, PCR products of all positive signal clones were sent for DNA sequencing (CRCHUL sequencing service, Laval University, PQ, Canada) as previously described (Sirard et al. 2005). Briefly, the resulting sequence traces were uploaded into a cDNA Library Manager program (coded by Genome Canada Bioinformatics) that automates and facilitates sequence analysis and clone identification (Vallee et al. 2005). For clone identification, sequence traces were uploaded into the cDNA Library Manager, trimmed (Phred software, www.phrap.org) and compared against a locally installed GenBank database (Basic Local Alignment Search Tool (BLAST); http://www.ncbi.nlm.nih.gov/blast/).

\section{Data mining: functional annotation and pathway analysis}

Differentially expressed genes were also used for pathway analysis and were imported into the Ingenuity Pathway Analysis (IPA) software (Ingenuity Systems; http://www.ingenuity.com, Mountain View, CA, USA). IPA was used to generate networks of genes and to perform a functional analysis associated with biological functions and molecular processes.

\section{Real-time PCR}

Validation of the microarray results was performed by the real-time PCR technique using the same RNA samples (nonamplified) as the microarrays. Five hundred nanograms of total RNA were reverse transcribed using the Transcriptor reverse transcriptase (Roche) with a mix of oligo dt (Applied Biosystems) and decamer (Applied Biosystems) according to manufacturer's instructions. All reactions were performed in triplicate with nonamplified cDNA in a final volume of $20 \mu \mathrm{l}$. The primers for each gene were designed using the Primer3 web interface (http://frodo.wi.mit.edu/cgi-bin/primer3/ primer3_www.cgi). Sequences, size of amplified product, and
GenBank accession numbers, as well as annealing temperatures, are presented in Table 4. For each candidate gene tested, a standard curve based on PCR products purified with the QIAquick PCR Purification Kit (Qiagen) and quantified with a spectrophotometer (NanoDrop ND-1000; NanoDrop Technologies) was included in the run. The standard curve consisted of five standards of the purified PCR products diluted from $0.10 \mathrm{pg}$ to $0.1 \mathrm{fg}$. Real-time PCR was performed on a LightCycler apparatus (Roche Diagnostics) using SYBR green incorporation for real-time monitoring of amplicon production. The reaction was performed in glass capillaries in a final volume of $20 \mu \mathrm{l}$ (Roche Diagnostics). Target transcripts were normalized with tyrosine 3-monooxygenase/tryptophan 5-monooxygenase activation protein, zeta polypeptide (YWHAZ), hypoxanthine phosphoribosyltransferase 1 (HPRT1; Table 4) using Geometric averaging normalization (GeNorm, http://medgen.ugent.be/ jvdesomp/genorm/). A one-way ANOVA and Tukey's multiple comparison tests were performed using Prism 4.0 (GraphPad software, La Jolla, CA, USA) to determine the statistically significant differences in mRNA levels between each GC stage.

\section{Declaration of interest}

The authors declare that there is no conflict of interest that could be perceived as prejudicing the impartiality of the research reported.

\section{Funding}

This project received support from L'Alliance Boviteq, Canada Research Chair and the Natural Science and Engineering Research Council of Canada.

\section{Acknowledgements}

The authors thank Nathalie Morin for her technical assistance during sample collection and embryo production; Eve-Lyne Sylvestre for her help with statistical analysis. We also thank Julie Nieminen for critical review of the manuscript. 


\section{References}

Abrink M, Grujic M \& Pejler G 2004 Serglycin is essential for maturation of mast cell secretory granule. Journal of Biological Chemistry 279 40897-40905. (doi:10.1074/jbc.M405856200)

Bedard J, Brule S, Price CA, Silversides DW \& Lussier JG 2003 Serine protease inhibitor-E2 (SERPINE2) is differentially expressed in granulosa cells of dominant follicle in cattle. Molecular Reproduction and Development 64 152-165. (doi:10.1002/mrd.10239)

Blondin P \& Sirard MA 1995 Oocyte and follicular morphology as determining characteristics for developmental competence in bovine oocytes. Molecular Reproduction and Development 41 54-62. (doi:10.1002/mrd.1080410109)

Blondin P, Bousquet D, Twagiramungu H, Barnes F \& Sirard MA 2002 Manipulation of follicular development to produce developmentally competent bovine oocytes. Biology of Reproduction 66 38-43. (doi:10. 1095/biolreprod66.1.38)

Buccione R, Schroeder AC \& Eppig JJ 1990a Interactions between somatic cells and germ cells throughout mammalian oogenesis. Biology of Reproduction 43 543-547. (doi:10.1095/biolreprod43.4.543)

Buccione R, Vanderhyden BC, Caron PJ \& Eppig JJ 1990b FSH-induced expansion of the mouse cumulus oophorus in vitro is dependent upon a specific factor(s) secreted by the oocyte. Developmental Biology 138 16-25. (doi:10.1016/0012-1606(90)90172-F)

Buratini J \& Price CA 2011 Follicular somatic cell factors and follicle development. Reproduction, Fertility, and Development 23 32-39. (doi:10.1071/RD10224)

Conti M, Hsieh M, Musa Zamah A \& Oh JS 2012 Novel signaling mechanisms in the ovary during oocyte maturation and ovulation. Molecular and Cellular Endocrinology 356 65-73. (doi:10.1016/j.mce. 2011.11.002)

De La Fuente R \& Eppig J 2001 Transcriptional activity of the mouse oocyte genome: companion granulosa cells modulate transcription and chromatin remodeling. Developmental Biology 229 224-236. (doi:10.1006/dbio.2000.9947)

Dieleman SJ, Hendriksen PJ, Viuff D, Thomsen PD, Hyttel P, Knijn HM, Wrenzycki C, Kruip TA, Niemann H, Gadella BM et al. 2002 Effects of in vivo prematuration and in vivo final maturation on developmental capacity and quality of pre-implantation embryos. Theriogenology $\mathbf{5 7}$ 5-20. (doi:10.1016/S0093-691X(01)00655-0)

Duranthon V \& Renard JP 2001 The developmental competence of mammalian oocytes: a convenient but biologically fuzzy concept. Theriogenology 55 1277-1289. (doi:10.1016/S0093-691X(01)00482-4)

Eder K, Guan H, Sung HY, Ward J, Angyal A, Janas M, Sarmay G, Duda E, Turner M, Dower SK et al. 2008 Tribbles-2 is a novel regulator of inflammatory activation of monocytes. International Immunology $\mathbf{2 0}$ 1543-1550. (doi:10.1093/intimm/dxn116)

Eppig JJ 1991 Intercommunication between mammalian oocytes and companion somatic cells. Bioessays 13 569-574. (doi:10.1002/bies. 950131105)

Eppig JJ, Wigglesworth K \& Pendola FL 2002 The mammalian oocyte orchestrates the rate of ovarian follicular development. PNAS 99 2890-2894. (doi:10.1073/pnas.052658699)

Eppig J, Pendola FL, Wigglesworth K \& Pendola JK 2005 Mouse oocytes regulate metabolic cooperativity between granulosa cells and oocytes: amino acid transport. Biology of Reproduction 73 351-357. (doi:10.1095/biolreprod.105.041798)

Fair T, Hulshof SC, Hyttel P, Greve T \& Boland M 1997 Nucleus ultrastructure and transcriptional activity of bovine oocytes in preantral and early antral follicles. Molecular Reproduction and Development 46 208-215. (doi:10.1002/(SICI)1098-2795(199702) 46:2<208::AID-MRD11>3.0.CO;2-X)

Gilbert I, Robert C, Dieleman S, Blondin P \& Sirard MA 2011 Transcriptional effect of the LH surge in bovine granulosa cells during the peri-ovulation period. Reproduction 141 193-205. (doi:10.1530/ REP-10-0381)

Gilchrist RB, Ritter LJ \& Armstrong DT 2004 Oocyte-somatic cell interactions during follicle development in mammals. Animal Reproduction Science 82-83 431-446. (doi:10.1016/j.anireprosci.2004.05.017)

Gilchrist RB, Lane M \& Thompson JG 2008 Oocyte-secreted factors: regulators of cumulus cell function and oocyte quality. Human Reproduction Update 14 159-177. (doi:10.1093/humupd/dmm040)
Hamel M, Dufort I, Robert C, Gravel C, Leveille MC, Leader A \& Sirard MA 2008 Identification of differentially expressed markers in human follicular cells associated with competent oocytes. Human Reproduction 23 1118-1127. (doi:10.1093/humrep/den048)

Hamel M, Dufort I, Robert C, Leveille MC, Leader A \& Sirard MA 2010a Identification of follicular marker genes as pregnancy predictors for human IVF: new evidence for the involvement of luteinization process. Molecular Human Reproduction 16 548-556. (doi:10.1093/molehr/ gaq051)

Hamel M, Dufort I, Robert C, Leveille MC, Leader A \& Sirard MA 2010b Genomic assessment of follicular marker genes as pregnancy predictors for human IVF. Molecular Human Reproduction 16 87-96. (doi:10.1093/ molehr/gap079)

Hegedus Z, Czibula A \& Kiss-Toth E 2007 Tribbles: a family of kinase-like proteins with potent signalling regulatory function. Cellular Signalling 19 238-250. (doi:10.1016/j.cellsig.2006.06.010)

Hillier SG 1991 Regulatory functions for inhibin and activin in human ovaries. Journal of Endocrinology 131 171-175. (doi:10.1677/joe.0. 1310171)

Homer HA, McDougall A, Levasseur M, Murdoch AP \& Herbert M 2005 Mad2 is required for inhibiting securin and cyclin B degradation following spindle depolymerisation in meiosis I mouse oocytes. Reproduction 130 829-843. (doi:10.1530/rep.1.00856)

Jiang JY, Xiong H, Cao M, Xia X, Sirard MA \& Tsang BK 2010 Mural granulosa cell gene expression associated with oocyte developmental competence. Journal of Ovarian Research 3 6. (doi:10.1186/17572215-3-6)

Joselin AP, Schulze-Osthoff K \& Schwerk C 2006 Loss of Acinus inhibits oligonucleosomal DNA fragmentation but not chromatin condensation during apoptosis. Journal of Biological Chemistry 281 12475-12484. (doi:10.1074/jbc.M509859200)

Kidder GM \& Vanderhyden BC 2010 Bidirectional communication between oocytes and follicle cells: ensuring oocyte developmental competence. Canadian Journal of Physiology and Pharmacology 88 399-413. (doi:10.1139/Y10-009)

Knijn HM, Fokker W, van der Weijden GC, Dieleman SJ \& Vos PL 2008 Effects of superovulation with oFSH and norgestomet/GnRH-controlled release of the $\mathrm{LH}$ surge on hormone concentrations, and yield of oocytes and embryos at specific developmental stages. Reproduction in Domestic Animals 47 177-183. (doi:10.1111/j.1439-0531.2008. 01305.x)

Koundrioukoff S, Polo S \& Almouzni G 2004 Interplay between chromatin and cell cycle checkpoints in the context of ATR/ATM-dependent checkpoints. DNA Repair 3 969-978. (doi:10.1016/j.dnarep.2004.03. 010)

Li R, Norman RJ, Armstrong DT \& Gilchrist RB 2000 Oocyte-secreted factor(s) determine functional differences between bovine mural granulosa cells and cumulus cells. Biology of Reproduction 63 839-845. (doi:10.1095/biolreprod63.3.839)

Makabe S, Naguro T \& Stallone T 2006 Oocyte-follicle cell interactions during ovarian follicle development, as seen by high resolution scanning and transmission electron microscopy in humans. Microscopic Research and Technique 69 436-449. (doi:10.1002/jemt.20303)

Mason AC, Roy R, Simmons DT \& Wold MS 2010 Functions of alternative replication protein $A$ in initiation and elongation. Biochemistry 49 5919-5928. (doi:10.1021/bi100380n)

Matzuk MM, Burns KH, Viveiros MM \& Eppig J 2002 Intercellular communication in the mammalian ovary: oocytes carry the conversation. Science 296 2178-2180. (doi:10.1126/science.1071965)

Memili E \& First NL 1998 Developmental changes in RNA polymerase II in bovine oocytes, early embryos, and effect of alpha-amanitin on embryo development. Molecular Reproduction and Development 51 381-389. (doi:10.1002/(SICI)1098-2795(199812)51:4<381::AID-MRD4>3.0. $\mathrm{CO} ; 2-\mathrm{G})$

Memili E, Dominko T \& First NL 1998 Onset of transcription in bovine oocytes and preimplantation embryos. Molecular Reproduction and Development 51 36-41. (doi:10.1002/(SICI)1098-2795(199809)51:1 < 36::AID-MRD4 > 3.0.CO;2-X)

Mermillod P, Dalbies-Tran R, Uzbekova S, Thelie A, Traverso JM, Perreau C, Papillier P \& Monget P 2008 Factors affecting oocyte quality: who is driving the follicle? Reproduction in Domestic Animals 43 (Suppl 2) 393-400. (doi:10.1111/j.1439-0531.2008.01190.x) 
Musacchio A \& Hardwick KG 2002 The spindle checkpoint: structural insights into dynamic signalling. Nature Reviews. Molecular Cell Biology 3 731-741. (doi:10.1038/nrm929)

Nakatani K, Nishioka J, Itakura T, Nakanishi Y, Horinouchi J, Abe Y, Wada H \& Nobori T 2004 Cell cycle-dependent transcriptional regulation of calmodulin-binding transcription activator 1 in neuroblastoma cells. International Journal of Oncology 24 1407-1412.

Ndiaye K, Fayad T, Silversides DW, Sirois J \& Lussier JG 2005 Identification of downregulated messenger RNAs in bovine granulosa cells of dominant follicles following stimulation with human chorionic gonadotropin. Biology of Reproduction 73 324-333. (doi:10.1095/biolreprod. 104.038026)

Rappsilber J, Ryder U, Lamond AI \& Mann M 2002 Large-scale proteomic analysis of the human spliceosome. Genome Research 12 1231-1245. (doi:10.1101/gr.473902)

Robertson I \& Nelson R 1998 Certification and identification of the embryo. In Manual of the International Embryo Transfer Society (IETS), 3rd edn. Eds DA Stringfellow \& SM Seidel. Savoy, IL, USA: IETS. pp 103-116.

Robert C, Gagne D, Bousquet D, Barnes FL \& Sirard MA 2001 Differential display and suppressive subtractive hybridization used to identify granulosa cell messenger RNA associated with bovine oocyte developmental competence. Biology of Reproduction 64 1812-1820. (doi:10.1095/biolreprod64.6.1812)

Salas TR, Petruseva I, Lavrik O \& Saintome C 2009 Evidence for direct contact between the RPA3 subunit of the human replication protein A and single-stranded DNA. Nucleic Acids Research 37 38-46. (doi:10.1093/nar/gkn895)

Silva CC \& Knight PG 1998 Modulatory actions of activin-A and follistatin on the developmental competence of in vitro-matured bovine oocytes. Biology of Reproduction 58 558-565. (doi:10.1095/biolreprod58.2.558)

Silverman GA, Bird PI, Carrell RW, Church FC, Coughlin PB, Gettins PG, Irving JA, Lomas DA, Luke CJ, Moyer RW et al. 2001 The serpins are an expanding superfamily of structurally similar but functionally diverse proteins. Evolution, mechanism of inhibition, novel functions, and a revised nomenclature. Journal of Biological Chemistry 276 33293-33296. (doi:10.1074/jbc.R100016200)

Sirard MA, Lambert RD, Menard DP \& Bedoya M 1985 Pregnancies after in-vitro fertilization of cow follicular oocytes, their incubation in rabbit oviduct and their transfer to the cow uterus. Journal of Reproduction and Fertility 75 551-556. (doi:10.1530/jrf.0.0750551)

Sirard MA, Parrish JJ, Ware CB, Leibfried-Rutledge ML \& First NL 1988 The culture of bovine oocytes to obtain developmentally competent embryos. Biology of Reproduction 39 546-552. (doi:10.1095/biolreprod39.3.546)

Sirard MA, Dufort I, Vallee M, Massicotte L, Gravel C, Reghenas H, Watson AJ, King WA \& Robert C 2005 Potential and limitations of bovine-specific arrays for the analysis of mRNA levels in early development: preliminary analysis using a bovine embryonic array. Reproduction, Fertility, and Development 17 47-57. (doi:10.1071/ RD04113)
Sirard MA, Richard F, Blondin P \& Robert C 2006 Contribution of the oocyte to embryo quality. Theriogenology 65 126-136. (doi:10.1016/j. theriogenology.2005.09.020)

Su YQ, Sugiura K, Wigglesworth K, O'Brien MJ, Affourtit JP, Pangas SA, Matzuk MM \& Eppig JJ 2008 Oocyte regulation of metabolic cooperativity between mouse cumulus cells and oocytes: BMP15 and GDF9 control cholesterol biosynthesis in cumulus cells. Development 135 111-121. (doi:10.1242/dev.009068)

Sun Y, Hao M, Luo Y, Liang CP, Silver DL, Cheng C, Maxfield FR \& Tall AR 2003 Stearoyl-CoA desaturase inhibits ATP-binding cassette transporter A1-mediated cholesterol efflux and modulates membrane domain structure. Journal of Biological Chemistry 278 5813-5820. (doi:10.1074/jbc.M208687200)

Vallee M, Gravel C, Palin MF, Reghenas H, Stothard P, Wishart DS \& Sirard MA 2005 Identification of novel and known oocyte-specific genes using complementary DNA subtraction and microarray analysis in three different species. Biology of Reproduction 73 63-71. (doi:10.1095/ biolreprod.104.037069)

Ward F, Enright B, Rizos D, Boland M \& Lonergan P 2002 Optimization of in vitro bovine embryo production: effect of duration of maturation, length of gamete co-incubation, sperm concentration and sire. Theriogenology 57 2105-2117. (doi:10.1016/S0093-691X(02)00696-9)

Wiemer KE, Watson AJ, Polanski V, McKenna Al, Fick GH \& Schultz GA 1991 Effects of maturation and co-culture treatments on the developmental capacity of early bovine embryos. Molecular Reproduction and Development 30 330-338. (doi:10.1002/mrd.1080300407)

Wrathall JH \& Knight PG 1995 Effects of inhibin-related peptides and oestradiol on androstenedione and progesterone secretion by bovine theca cells in vitro. Journal of Endocrinology 145 491-500. (doi:10. 1677/joe.0.1450491)

Zhang L, Ge L, Parimoo S, Stenn K \& Prouty SM 1999 Human stearoyl-CoA desaturase: alternative transcripts generated from a single gene by usage of tandem polyadenylation sites. Biochemical Journal 340 255-264. (doi:10.1042/0264-6021:3400255)

Zhang F, Wu J \& Yu X 2009 Integrator3, a partner of single-stranded DNAbinding protein 1, participates in the DNA damage response. Journal of Biological Chemistry 284 30408-30415. (doi:10.1074/jbc.M109.039404)

Zhou Z, Licklider LJ, Gygi SP \& Reed R 2002 Comprehensive proteomic analysis of the human spliceosome. Nature 419 182-185. (doi:10.1038/ nature01031)

Received 1 December 2011

First decision 24 January 2012

Revised manuscript received 22 March 2012

Accepted 27 March 2012 